\title{
Endogenous Production of Carbon Monoxide in
}

\section{Normal and Erythroblastotic Newborn Infants}

\author{
M. Jeffrey Maiseis, Ambadas Pathak, Nicholas M. Neison, \\ David G. Nathan, and Clement A. Smith \\ From the Laboratory for Neonatal Research, Boston Hospital for Women, \\ Division of Hematology of the Children's Hospital Medical Center, and \\ Department of Pediatrics, Harvard Medical School, Boston, Massachusetts 02115
}

\begin{abstract}
A B S T R A C T The endogenous production of carbon monoxide $\left(\dot{\mathrm{V}}_{\mathrm{CO}}\right)$ in newborn infants was measured by serial determinations of blood carboxyhemoglobin during rebreathing in a closed system. Mean $\dot{\mathrm{V}}_{\mathrm{Co}}$ in nine full-term infants was $13.7 \pm 3.6 \mu \mathrm{l} \mathrm{CO} / \mathrm{kg}$ per $\mathrm{hr}$ (SD), and in four erythroblastotic infants $\dot{\mathrm{V}}_{\text {Co }}$ ranged from 37 to $154 \mu \mathrm{l} \mathrm{CO} / \mathrm{kg}$ per hr preceding exchange transfusion. Mean red cell life-span (MLS) and total bilirubin production were calculated from $\dot{V}_{\text {Co. }}$ MLS in normal newborns was $88 \pm 15$ days (SD), and bilirubin production was $8.5 \pm 2.3 \mathrm{mg} / \mathrm{kg}$ per $24 \mathrm{hr}$. This is more than twice the amount of bilirubin normally produced in the adult per kilogram of body weight. Normal infants achieved a net excretion of bilirubin of at least $5.6 \pm 2.3 \mathrm{mg} / \mathrm{kg}$ per $24 \mathrm{hr}$ (SD) as calculated from the bilirubin production and the measured rise in serum bilirubin concentration.

The measurement of $\dot{V}_{\text {Co }}$ should prove valuable in the study of red blood cell survival and bilirubin metabolism in the newborn infant.
\end{abstract}

\section{INTRODUCTION}

The recent studies of Coburn and coworkers (1-3) have confirmed the original observations by Sjöstrand (4-6) that carbon monoxide ( $\mathrm{CO}$ ) is endogenously produced in normal man, and that approximately 1 mole of $\mathrm{CO}$ is produced per mole of heme catabolized (2).

Interest in neonatal hemoglobin turnover has led previous investigators (7-10) to measure blood carboxy-

Dr. Maisels' present address is the Department of Hematology, Walter Reed Army Institute of Research, Washington, D. C. 20012.

This work was presented in part at the Annual Meeting of the Society for Pediatric Research, Atlantic City, New Jersey, May 1969.

Received for publication 2 January 1970 and in revised form 22 June 1970. hemoglobin $(\mathrm{COHb})^{1}$ levels in normal newborn infants and in those with jaundice of hemolytic and nonhemolytic origin. In hemolytic disease of the newborn they demonstrated an elevated level of $\mathrm{COHb}$ which was assumed to be due to an increase in $\mathrm{CO}$ production $\left(\dot{\mathrm{V}}_{\mathrm{CO}}\right)$ resulting from increased hemoglobin destruction. Although a correlation has, indeed, been shown to exist between blood $\mathrm{COHb}$ and $\dot{\mathrm{V}}_{\mathrm{Co}}(11,12)$ the relationship is too uncertain to derive an accurate indication of hemoglobin turnover from $\mathrm{COHb}$ (11).

Wranne (13-15) and Fällström $(12,16)$ have measured the pulmonary excretion of $\mathrm{CO}$ in newborn infants. This measurement may not accurately reflect $\mathrm{CO}$ production because of the difficulty in achieving a steady state between $\dot{V}_{C O}$, the critical measurement, and the rate of $\mathrm{CO}$ excretion via the lung (11).

We have adapted Coburn's rebreathing system for the measurement of $\dot{\mathrm{V}}_{\mathrm{CO}}(1,17)$ to the study of newborn infants. With this technique an alteration in $\mathrm{CO}$ production can be measured within minutes after it has occurred (18), and we have been able to calculate hemoglobin catabolism, red blood cell survival, and bilirubin production in the newborn infant.

\section{METHODS}

\section{Rebreathing circuit}

The closed rebreathing circuit is shown in Fig. 1. The method of sealing the infant's face into the rebreathing mask is similar to that described by Cross (19). The infant's face emerges through a pneumatic $\operatorname{cuff}^{2}(a)$ which seals against the face and the surrounding plastic ring (b) onto which a lid is sealed by spring clips. A stop cock (e) allows gas sampling and $\mathrm{CO}$ addition at the end of the procedure (see below). The blower $(g)$ circulates air at approximately 15 liters $/ \mathrm{min}$. At

\footnotetext{
1 The terms $\mathrm{COHb}, \mathrm{COHb} \%$, and $\mathrm{COHb}$ per cent saturation' are used interchangeably throughout this paper. All imply the per cent of hemoglobin saturated with carbon monoxide.

2 Dunlop Company, Ltd., Manchester, England.
} 
this rate of flow through the $\mathrm{CO}_{2}$ absorbent $(f)(650 \mathrm{ml}$ of Baralyme), less than $1 \% \mathrm{CO}_{2}$ is detectable in the circuit. Humidified oxygen is added via a $50 \mathrm{ml}$ syringe at $e$ in amounts sufficient to maintain a constant circuit volume.

A thin walled rubber tube, $36 \mathrm{~cm}$ long and $6 \mathrm{~cm}$ in diameter, is sealed inside a solid plastic tube $(c)$ as illustrated. Rubber stoppers at either end have an outlet for the circulating gas and an additional inlet at one end for oxygen (e). This device allows the addition of oxygen when required without the use of a rubber bag (1) which could act as "dead space" and prevent complete circulation of $\mathrm{CO}$ throughout the sytem. A Krogh spirometer $(d)$ is connected to an outlet from the plastic tube and reflects volume changes occurring in the circuit. The use of the spirometer outside of the circuit allows the volume of the system to be kept as small as possible (about 2 liters).

\section{Conduct of study}

The infant was placed in the system, and the oxygen tension was adjusted to approximately $150 \mathrm{~mm} \mathrm{Hg}$. Thereafter, as oxygen was consumed by the infant, it was replaced so as to maintain circuit volume constant as measured by the spirometer. Oxygen tension was monitored frequently throughout the study and adjusted, if necessary, by the addition of extra oxygen. After rebreathing had continued for at least $15 \mathrm{~min}$ $(1,17,20)$ the first blood sample was taken. Subsequent samples were taken at 30 -min intervals for $1 \mathrm{hr}$. Blood was taken anaerobically either from an indwelling, size 21 , scalp vein needle inserted into an antecubital vein, or from free flowing arterialized heel prick samples, the same method of sampling being used throughout a given study. $1 \mathrm{ml}$ of blood was sufficient for duplicate analyses.

Total time involved in the study including the initial equilibration, determination of the dilution factor (see below), insertion of an indwelling needle, and settling the baby into the system, was usually close to $3 \mathrm{hr}$, by which time most full-term infants were showing signs of restlessness, crying, and/or hunger. When these occurred, leaks ${ }^{s}$ were apt to develop around the baby's face. At the end of the period of observation of the rate of increase of COHb, $0.92 \mathrm{ml}$ (STPD) of $99.5 \% \mathrm{CO}$ gas $^{6}$ was added to the system at $e$ (Fig. 1), and a final blood sample was taken 45 min later. The maximum blood $\mathrm{CO}$ level measured after the addition of $\mathrm{CO}$ was $0.736 \mathrm{ml} / 100 \mathrm{ml}$ or $3.48 \%$ of hemoglobin saturated with $\mathrm{CO}(1)$.

\section{Blood analysis}

The blood samples were analyzed for $\mathrm{CO}$ by liberating bound $\mathrm{CO}$ with acidified potassium ferricyanide and a hemolyzing agent (Triton X-100; Rohm and Haas Co., Philadelphia, $\mathrm{Pa}$.). The liberated blood gases were then extracted under vacuum using the modified microgasometer described by Natelson and Stellate (21) followed by injection into a gas chromatograph (Perkin-Elmer 154L). The method of gas injection was modified from Farhi, Edwards, and Homma (22) where the connecting tube leading from the upper two-way

${ }^{3}$ Baralyme ${ }^{R}$ is obtainable from Warren E. Collins, Inc., Braintree, Mass.

4 IL $113 \mathrm{pH} / \mathrm{gas}$ analyzer $\mathrm{PO}_{2}$ electrode; Instrumentation Laboratory, Inc., Watertown, Mass.

- Leaks could be detected by a number of means, including rapid fall of the spirometer bell, and could be corrected by increasing the inflation of the pneumatic cuff seal or by wedging the infant's face into the cuff more firmly by means of an inflatable pillow.

${ }^{6}$ CO 99.5\%; Matheson Co., Inc., East Rutherford, N. J.

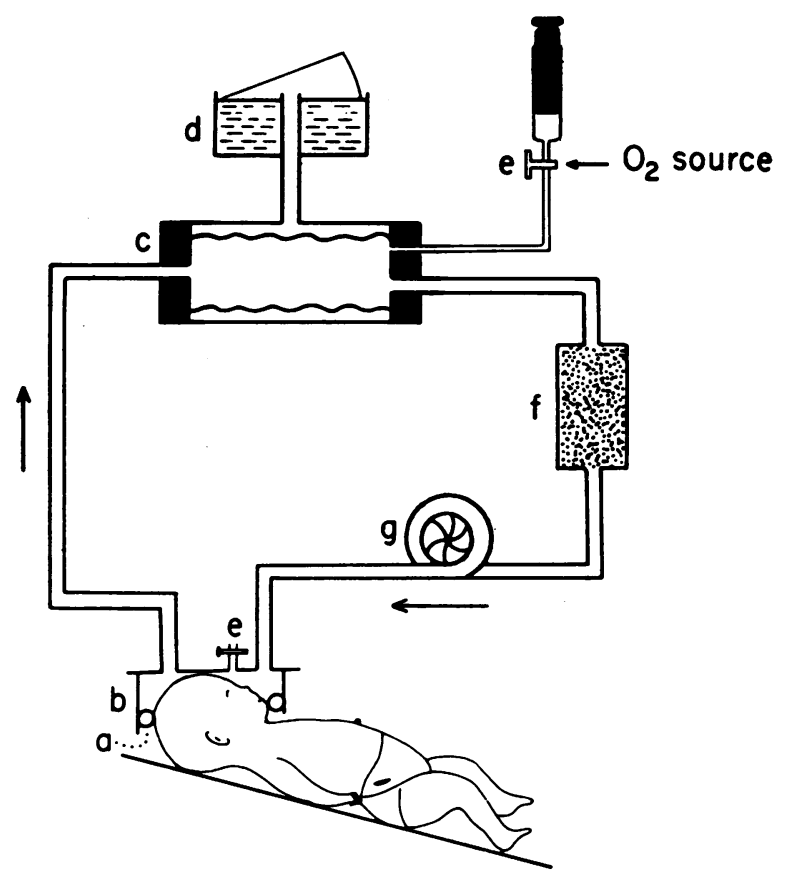

FIGURE 1 Rebreathing circuit showing pneumatic cuff (a), plastic ring $(b)$, plastic tube with thin-walled rubber tube $(c)$, spirometer $(d)$, stopcocks $(e), \mathrm{CO}_{2}$ absorbent $(f)$, variable speed blower $(g)$, and oxygen source.

stopcock of the microgasometer is connected to two limbs of a four-arm, four-way stopcock. Blood samples of $0.24 \mathrm{ml}$ were drawn up followed by reagents in the following order: $0.025 \mathrm{ml}$ of $1 \mathrm{~N}$ lactic acid, $0.024 \mathrm{ml}$ of $10 \%$ potassium ferricyanide, $0.1 \mathrm{ml}$ of a solution containing two parts $30 \%$ Triton X-100 in saline and one part caprylic alcohol. After the sample and reagents were brought down into the lower reaction chamber under vacuum, the mixtures were agitated for $4 \mathrm{~min}$ using the automatic shaker. The extracted gas was then transferred into the carrier stream of helium by the method described by Farhi et al. (22). Helium at a flow of $50 \mathrm{ml} / \mathrm{min}$ carried the gas through the water ${ }^{7}$ and $\mathrm{CO}_{2}^{8}$ absorbers into the gas chromatograph. Oxygen, nitrogen, and $\mathrm{CO}$ were separated on a 1 inch $\times 6 \mathrm{ft}$ column of $13 \mathrm{x}$ molecular sieves. Column (and detector) temperature and pressure were $30^{\circ} \mathrm{C}$ and $10 \mathrm{PSIG}$, respectively. Voltage change across the thermistor detector bridge was recorded by a $1 \mathrm{mv}$ potentiometric recorder (E. $\mathrm{H}$. Sargent \& Co., Springfield, N. J.; model S-72180-25).

The apparatus was calibrated by introducing a $3 \mathrm{ml}$ sample of $\mathrm{CO}^{\circ}$ of known concentration into the microgasometer and thence to the chromatograph. The blood $\mathrm{COHb}$ saturation was calculated by dividing $\mathrm{CO}$ content in milliliter per $100 \mathrm{ml}$ (STPD) by the CO capacity. The CO capacity was determined by multiplying the hemoglobin concentration in grams per $100 \mathrm{ml}$ by 1.34 (23). All analyses were performed in duplicate or triplicate. SD of the analysis was $\pm 0.04 \% \mathrm{COHb}$ (coefficient of variation $1.7 \%$ ). Hemoglobin was measured as cyanmethemoglobin (24). Serum bilirubin concentration was measured by the method of White, Haidar, and Rheinhold (25).

7 Drierite; W. A. Hammond Drierite Company, Xenia, Ohio. 8 Ascarite; Arthur H. Thomas Co., Philadelphia, Pa.

- CO 0.0950\%; analyzed by and obtained from Matheson Co., Inc., East Rutherford, N. J. 


\section{Calculations}

CO production. The $\dot{\mathrm{V}}_{\text {co }}$ was calculated according to the equation

$$
\dot{\mathrm{V}}_{\mathrm{CO}}=\Delta \mathrm{COHb} \% \times \frac{\mathrm{CO}_{\mathrm{D}}}{\Delta \mathrm{COHb} \% \mathrm{D}}
$$

where $\dot{\mathrm{V}}_{\mathrm{Co}}$ is $\mathrm{CO}$ production in milliliters per hour (STPD), and $\Delta \mathrm{COHb} \%$ is the average hourly increase in the per cent saturation of hemoglobin with $\mathrm{CO}(1)$.

The term $\mathrm{CO}_{\mathrm{D}} / \triangle \mathrm{COHb} \% \mathrm{D}$ is the dilution of added $\mathrm{CO}$ in the body and is determined by adding $0.92 \mathrm{ml}$ (STPD) of $99.5 \% \mathrm{CO}$ to the circuit $\left(\mathrm{CO}_{\mathrm{D}}\right)$, and therefore to the body stores, and measuring the resultant increase in the blood $\mathrm{COHb}$ per cent $(\triangle \mathrm{COHb} \% \mathrm{D})$.

Mean red cell life span (MLS). In the steady state, the mean red cell life span (MLS) is expressed by the equation

$$
\operatorname{MLS} \text { (days) }=\frac{\mathrm{T}_{\text {home }}(\mu \text { moles })}{\dot{\mathrm{V}}_{\text {heme }}(\mu \text { moles } / 24 \mathrm{hr})}
$$

where $T_{\text {heme }}$ is the total circulating heme and $\dot{V}_{\text {heme }}$ is the rate of breakdown of circulating heme (17).

Total circulating hemoglobin $\left(\mathrm{T}_{\mathrm{Hb}}\right)$ was determined by dividing the dilution factor $\mathrm{CO}_{\mathrm{D}} / \Delta \mathrm{COHb} \% \mathrm{D}$ (see equation 1) by $1.34(20)$. $\mathrm{T}_{\text {heme }}$ is derived from the total hemoglobin in grams $\left(\mathrm{gT}_{\mathrm{Hb}}\right)$ as follows:

$$
\mathrm{T}_{\text {hemo }}(\mu \text { moles })=\frac{\mathrm{g} \mathrm{T}_{\mathrm{Hb}}}{0.017}
$$

where the factor 0.017 is grams of hemoglobin per $\mu$ mole.

The denominator in equation 2 is derived directly from $\dot{\mathrm{V}}_{\text {Co }}$ and a correction made for the "early labeled" $\mathrm{CO}$ peak; that is, CO not produced by senescent circulating red cells (see Discussion). In this study it was assumed that only $75 \%$ of the measured $\dot{\mathrm{V}}_{\text {co }}$ was derived from breakdown of circulating red cells (26). Equation 2 then becomes:

$$
\mathrm{MLS}_{\text {oorr }}=\frac{\mathrm{gT}_{\mathrm{Hb}} / 0.017}{0.75 \times \dot{\mathrm{V}}_{\mathrm{Co}} \times 44.6 \times 24}
$$

where $\dot{\mathrm{V}}_{\mathbf{C O}}$ is in milliliters per hour STPD, $\mathrm{T}_{\mathbf{H b}}$ is in grams, and MLS $_{\text {corr }}$ is the mean life span corrected for early labeled CO. The calculation of both total hemoglobin and of $\dot{\mathrm{V}}_{\text {co }}$ (see equation 1) requires a measurement of $\mathrm{CO}$ dilution. This term, therefore, cancels, and the measurement of total circulating hemoglobin by $\mathrm{CO}$ dilution and any errors involved therein should not affect the calculation of mean life span. ${ }^{10}$

$$
\mathrm{MLS}_{\text {oorr }}=\frac{5.46 \times 10^{-2}}{\Delta \mathrm{COHb} \%}
$$

Bilirubin production, retention, and excretion. $\quad \dot{\mathrm{V}}_{\mathrm{Co}}$ has been shown to reflect bilirubin production in man (27). Bilirubin production was therefore calculated directly from the measured $\dot{V}_{\text {co }}$ ( $\mu$ moles/hr) and the molecular weight of bilirubin:

Bilirubin production $(\mathrm{mg} / \mathrm{kg}$ per $24 \mathrm{hr}$ )

$$
=\frac{\dot{\mathrm{V}}_{\mathrm{co}}(\mu \text { moles } / \mathrm{hr}) \times 0.585 \times 24}{\text { body weight }(\mathrm{kg})}
$$

where the factor 0.585 is the $\mathrm{mg}$ of bilirubin per $\mu$ mole.

${ }^{10}$ The rate of rise of $\mathrm{COHb}$ will itself be affected by the true size of the total CO pool. When this pool differs significantly from the $\mathrm{CO}$ binding capacity of the total circulating hemoglobin (in circumstances where significant amounts of $\mathrm{CO}$ are bound outside the circulation), the calculation of circulating hemoglobin cannot be based on $\mathrm{CO}$ dilution.
The "retention" of intravascular bilirubin was calculated from the measured rise in serum bilirubin concentration per $24 \mathrm{hr}$ and the plasma volume.

The total bilirubin space has not been measured in the normal newborn infant, but studies in adults suggest that it is equal to about twice the plasma volume (28). Total body bilirubin was therefore calculated by multiplying the total intravascular bilirubin by two. Excretion of bilirubin was assumed to equal production minus retention.

Plasma volume was calculated from the red cell volume (RCV) and the whole body hematocrit $(0.87 \times$ venous hematocrit) (29). RCV was determined from CO dilution and the hematocrit (30).

$$
\mathrm{RCV} \mathrm{ml}=\frac{\mathrm{CO}_{\mathrm{D}}}{\text { measured increase in } \mathrm{CO} \mathrm{ml} / \mathrm{ml}} \times \text { hematocrit. }
$$

\section{Subjects}

Nine normal newborn infants of $40-41$ wk gestation were studied in the first 3 days of life. Permission for the studies was obtained from their informed mothers. None of the mothers received barbiturates during labor (18) or volatile anesthetics during delivery (9). Ages at the time of study ranged from 27 to $57 \mathrm{hr}$, and the maximum bilirubin concentration in any of these infants before their discharge on the 5th day was $8 \mathrm{mg} / 100 \mathrm{ml}$. Two of the mothers smoked. Their infants were 40 and $47 \mathrm{hr}$ old, respectively, at the time of study, and their levels of blood $\mathrm{COHb}$ were well within the normal range (7-9).

Four infants with erythroblastosis were studied immediately before the first exchange transfusion. Three of these infants were delivered vaginally; one was an infant of a diabetic mother who was delivered by elective cesarean section under spinal anesthesia. One mother smoked up to the time of delivery, and the possible effect of this on $\dot{V}_{\text {co }}$ is discussed below. Rebreathing periods in these infants varied from 30 $\min$ to $1 \mathrm{hr}$.

\section{RESULTS}

CO production and mean red cell life span (MLS). The results of studies of $\mathrm{CO}$ production in normal and erythroblastotic infants are shown in Fig. 2. The individual data are presented in Tables I and II. The mean rate of $\mathrm{CO}$ production in the normal infants was $13.7 \pm 3.6 \mu \mathrm{l} \mathrm{CO} / \mathrm{kg}$ per hr (SD). In erythroblastotic infants $\dot{\mathrm{V}}_{\mathrm{CO}}$ ranged from 37 to $154 \mu \mathrm{l} \mathrm{CO} / \mathrm{kg}$ per hr. The MLS of the nine normal infants was $88 \pm 15$ days (SD).

Bilirubin metabolism. Fig. 3 shows the results of bilirubin production plotted against bilirubin retention in the normal infants.

Reference to Fig. 3 shows that if none of the infants were capable of excreting bilirubin, production would equal retention and all points would fall on the line of identity. The fact that all points fall below the line implies that all of these infants were capable of excreting some bilirubin. The mean rate of bilirubin production in the normal infants was $8.5 \pm 2.32 \mathrm{mg} / \mathrm{kg}$ per $24 \mathrm{hr}$ (sD), and mean excretion was $5.6 \pm 2.29 \mathrm{mg} / \mathrm{kg}$ per $24 \mathrm{hr}$ (SD). Bilirubin production in the erythroblastotic infants ranged from 23 to $96 \mathrm{mg} / \mathrm{kg}$ per $24 \mathrm{hr}$. 


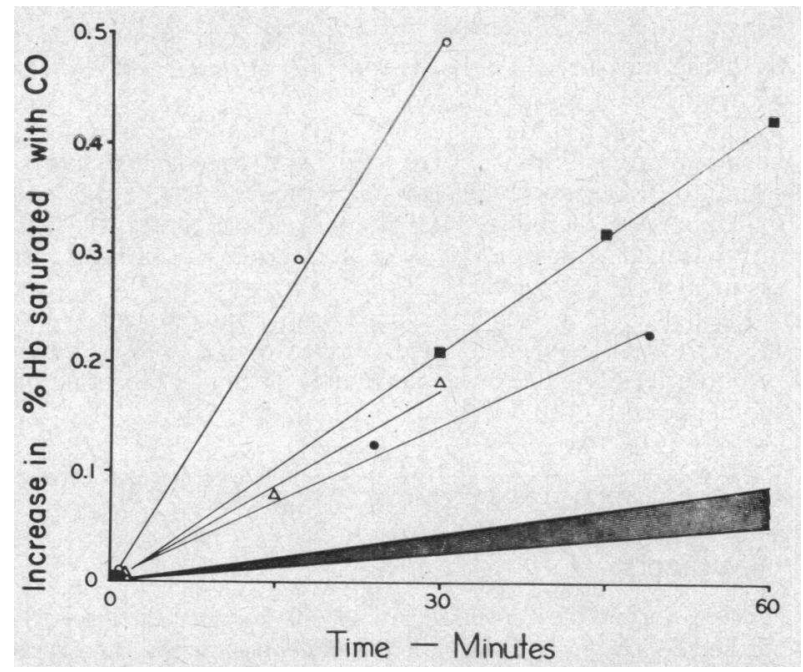

FIGURE 2 Increase in per cent hemoglobin saturated with $\mathrm{CO}$ in four infants with erythroblastosis fetalis in the rebreathing system. Regression lines were drawn by the least square methcd. Shaded area represents range of values found in nine normal fullterm infants. Infants (see Table II): Con, open circles; Cam, squares; Lam, triangles; Sul, closed circles.

\section{DISCUSSION}

These studies provide direct measurements of $\mathrm{CO}$ production in newborn infants and demonstrate the feasibility of applying this technique to the study of a variety of clinical conditions in the neonatal period. $\dot{\mathrm{V}}_{\mathrm{CO}}$ in normal newborns is about twice that in adults when expressed per kilogram of body weight. This can be explained by the more rapid turnover of a larger relative mass of circulating hemoglobin as well as a greater contribution from heme catabolism outside of the circula- tion $(26,33)$. The MLS of 88 days corresponds well with nearly all of the published data on MLS in the newborn determined by various methods (33-36). The results also suggest that the newborn infant's ability to excrete bilirubin may be much greater than has been previously appreciated. These conclusions are based on calculations that are dependent upon certain assumptions and upon accurate measurement of $\mathrm{CO}$ accumulation $\left(\dot{\mathrm{V}}_{\mathrm{CO}}\right)$ in the blood of newborns.

To assess the accuracy and reproducibility of the $\dot{\mathrm{V}}_{\mathrm{CO}}$ measurement would require repeated studies on individual infants within a short space of time which was not possible. Analysis of $\mathrm{CO}$ in duplicate blood samples was satisfactory, but one important source of measurement error may have resulted from the clinical circumstances which necessitated the construction of regression lines from only three samples. This uncertainty may have contributed to the rather high standard deviation of the regression lines in the normal infants which varied from 0.006 to $0.046 \mathrm{COHb}$ per cent saturation per hour (equivalent to a measured $\dot{\mathrm{V}}_{\text {Co }}$ of $1.3-9.9 \mu \mathrm{l} / \mathrm{kg}$ per $\mathrm{hr}$ ). The high initial $\mathrm{COHb}$ in infant Con (Table II) may have been influenced by maternal smoking, but the elevated $\dot{\mathrm{V}}_{\mathrm{CO}}$ reflected hemolysis as indicated by the reticulocyte count of $22 \%$.

The calculation of MLS (equation 2) assumes that a steady state existed. Normal newborn infants may show significant changes in blood volume and hematocrit during the first $24 \mathrm{hr}$ of life mainly due to changes in plasma volume $(31,37,38)$, but red cell volume remains stable during the first 3 days of life (31) and no real decrease in hemoglobin concentration occurs until some time between the 1 st and $3 \mathrm{rd}$ wk of life (39). In view of

TABLE I

CO Production in Normal Infants

\begin{tabular}{lcccccccccc}
\hline \multicolumn{1}{c}{ Infant } & $\begin{array}{c}\text { Gesta- } \\
\text { tion }\end{array}$ & Age & Weight & $\begin{array}{c}\text { Reticu- } \\
\text { locytes }\end{array}$ & $\begin{array}{c}\text { Hemo- } \\
\text { globin }\end{array}$ & $\begin{array}{c}\text { Dilution } \\
\text { factor }\end{array}$ & $\begin{array}{c}\text { Initial } \\
\text { COHb }\end{array}$ & $\begin{array}{c}\text { Hourly } \\
\text { increase } \\
\text { in COHb }\end{array}$ & $\begin{array}{c}\text { Vico } \\
\text { Mean red } \\
\text { cell life } \\
\text { span }\end{array}$ \\
\hline & $w k$ & $h r$ & $k g$ & $\%$ & $g / 100 m l$ & $m l$ & $\%$ & $\%$ & $\mu l / k g / h r$ & days \\
Faz & 41 & 27 & 3.16 & 6.0 & 19.3 & 66.1 & 0.545 & 0.059 & 12.3 & 93 \\
Blo & 40 & 29 & 3.28 & 5.4 & 19.3 & 79.0 & 0.567 & 0.089 & 21.5 & 61 \\
Fit & 41 & 38 & 3.57 & 7.4 & 21.0 & 98.3 & 0.494 & 0.052 & 14.5 & 105 \\
Wal & 40 & 40 & 3.36 & 5.6 & 19.6 & 72.1 & $0.447^{*}$ & 0.066 & 14.1 & 83 \\
Bra & 41 & 48 & 3.23 & 5.4 & 19.5 & 53.5 & 0.610 & 0.052 & 8.6 & 106 \\
Wo & 40 & 54 & 3.32 & 4.8 & 18.9 & $75.2 \pm$ & 0.405 & 0.071 & 16.0 & 77 \\
Wil & 41 & 55 & 3.52 & 4.8 & 19.3 & $82.0 \pm$ & 0.791 & 0.058 & 13.5 & 95 \\
Sla & 40 & 55 & 3.54 & 7.0 & 16.5 & 71.5 & 0.636 & 0.056 & 11.3 & 98 \\
Gai & 40 & 57 & 3.29 & 8.0 & 16.5 & 51.2 & $0.580^{*}$ & 0.073 & 11.3 & 75 \\
Mean \pm SD & 40.4 & 44.8 & 3.36 & $6.0 \pm$ & $18.9 \pm$ & $72.1 \pm$ & $0.564 \pm$ & $0.064 \pm$ & $13.7 \pm$ & $88.1 \pm$ \\
& & & & 1.16 & 1.47 & 14.41 & 0.114 & 0.0118 & 3.64 & 15.1 \\
\hline
\end{tabular}

$\mathrm{COHb}=$ per cent saturation of hemoglobin with $\mathrm{CO} ; \dot{\mathrm{V}}_{\mathrm{Co}}=\mathrm{CO}$ production.

* Mother a smoker.

‡ Calculated from estimated blood volume based on venous hematocrit (31).

4 M. J. Maisels, A. Pathak, N. M. Nelson, D. G. Nathan, and C. A. Smith 
TABLE II

CO Production in Erythroblastotic Infants

\begin{tabular}{|c|c|c|c|c|c|c|c|c|c|c|}
\hline Infant & $\begin{array}{c}\text { Blood } \\
\text { group } \\
\text { incom- } \\
\text { patibility }\end{array}$ & $\begin{array}{l}\text { Gesta- } \\
\text { tion }\end{array}$ & Age & Weight & $\begin{array}{l}\text { Reticu- } \\
\text { locytes }\end{array}$ & $\begin{array}{l}\text { Hemo- } \\
\text { globin }\end{array}$ & $\begin{array}{l}\text { Dilution } \\
\text { factor }\end{array}$ & $\begin{array}{l}\text { Initial } \\
\text { COHb }\end{array}$ & $\begin{array}{l}\text { Hourly } \\
\text { increase } \\
\text { in COHb }\end{array}$ & $\dot{\mathrm{V}} \mathrm{co}$ \\
\hline & & $w k$ & $h r$ & $\mathrm{~kg}$ & $\%$ & $\mathrm{~g} / 100 \mathrm{ml}$ & $m l$ & $\%$ & $\%$ & $\mu l / k g / h r$ \\
\hline Sul & $\mathrm{Rh}$ & 38 & 2 & 2.98 & 14.6 & 12.8 & $38.4^{*}$ & 1.131 & 0.286 & 36.9 \\
\hline Lam & $\mathrm{Rh}$ & 36 & 3 & 2.75 & 10.8 & 11.5 & $31.7^{*}$ & 0.610 & 0.355 & 40.9 \\
\hline Cam & A-O & 37 & 3 & 3.60 & 17.3 & 15.8 & 60.9 & 1.502 & 0.434 & 73.5 \\
\hline Con & $\mathrm{Rh}$ & 37 & 5 & 2.68 & 22.2 & 15.5 & 41.7 & $5.739 \ddagger$ & 0.992 & 154.3 \\
\hline Mean values & & 37 & 3.2 & 3.00 & 16.2 & 13.9 & 43.2 & 2.246 & 0.517 & 76.4 \\
\hline
\end{tabular}

$\mathrm{COHb}=$ per cent saturation of hemoglobin with $\mathrm{CO} ; \dot{\mathrm{V}}_{\mathrm{CO}}=\mathrm{CO}$ production.

* Calculated from estimated blood volume of $75 \mathrm{ml} / \mathrm{kg}(31,32)$.

$\ddagger$ Mother a smoker.

this and the brief duration of the study, the steady-state assumption is probably valid.

The determination of total circulating hemoglobin from $\mathrm{CO}$ dilution assumes that $\mathrm{CO}$ dilution measures circulating red cell volume. Red cell volumes measured by the $\mathrm{CO}$ method are $6-16 \%$ higher than that measured by the use of ${ }^{51} \mathrm{Cr}(30,40)$. This has been attributed to the binding of some of the administered $\mathrm{CO}$ by extravascular substances, chiefly myoglobin. No simultaneous measurements using $\mathrm{CO}$ and ${ }^{51} \mathrm{Cr}$ have been performed in newborn infants. The newborn has a relatively small muscle mass and probably less myo- globin relative to his hemoglobin mass; therefore, we did not apply a correction for nonhemoglobin binding of $\mathrm{CO}$. The calculated mean red cell volume in the seven infants in whom $\mathrm{CO}$ dilution was measured was $45 \mathrm{ml} / \mathrm{kg}$ which is only $7 \%$ greater than the figure of $41.9 \mathrm{ml} / \mathrm{kg}$ calculated from the data of Mollison, Veall, and Cutbush in 33 infants with hematocrits between 40.2 and $66.2 \%$ (29).

The turnover of bilirubin has not previously been measured in newborn infants because of the difficulty in achieving steady-state conditions and the undesirability of administering labeled bilirubin to infants. Bilirubin

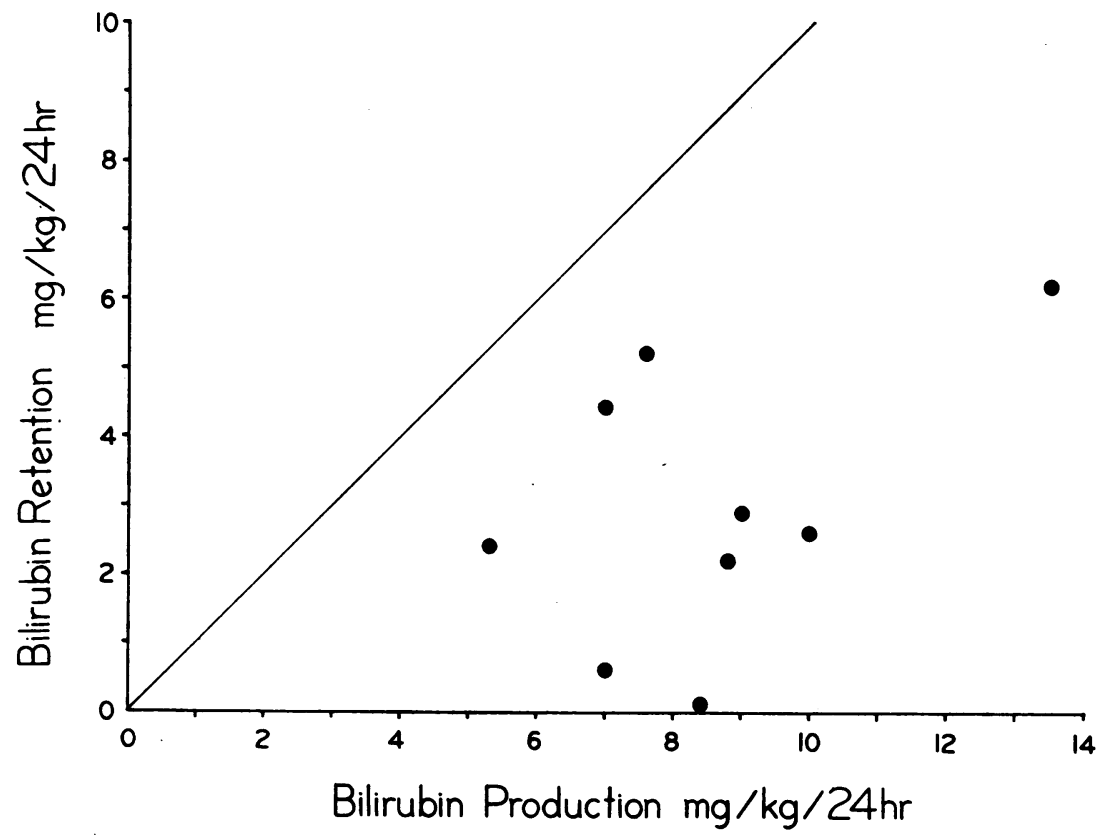

FIGURE 3 Bilirubin production plotted against retention in nine normal full-term infants (closed circles). The line drawn is that on which points would fall if production equaled retention (i.e., no excretion of bilirubin occurring). 
is mainly produced by catabolism of circulating hemoglobin, but also by heme turnover in several other areas including the bone marrow and any tissue containing molecules with heme as a prosthetic group (41), of which the liver appears to be the most important source (42-44). The bilirubin from sources other than circulating hemoglobin is commonly referred to as the "early labeled peak" $(44,45)$. Our calculations of bilirubin turnover depend on the assumption that the production of $\mathrm{CO}$ and bilirubin are proportional. Engel, Berk, Rodkey, Howe, and Berlin (27) measured $\dot{\mathrm{V}}_{\mathrm{CO}}$ and endogenous bilirubin production in normal subjects and patients with hemolytic disease. They found an excellent correlation $(r=0.96)$ between $\dot{\mathrm{V}}_{\mathrm{CO}}$ and bilirubin production.

An early labeled $\mathrm{CO}$ peak as well as early labeled stercobilin has been demonstrated in patients with ineffective erythropoiesis (45). Two studies have been reported concerning the early labeled peak in newborn infants. Vest, Strebel, and Hauenstein (26), using glycine $-{ }^{15} \mathrm{~N}$ in two full-term infants calculated that at least $21-25 \%$ of bile pigment excreted in the feces was not derived from senescent erythrocytes. Vest (33) further reported that in two premature infants this fraction was more than $30 \%$.

Jaundice in the normal newborn infant has been attributed to the inability of the liver to conjugate bilirubin due to decreased activity of the glucuronyltransferase enzyme (46-48) in the face of a relatively "normal" rate of bilirubin production. However, our results indicate that normal newborns produce bilirubin at more than twice the adult rate (per kilogram per $24 \mathrm{hr}$ ). Recent studies have suggested that inability to conjugate bilirubin may not be the most important rate limiting step in the excretion of bilirubin in the newborn (49-51). Failure of bilirubin uptake and excretion (51) and increased bilirubin production possibly play important roles in this complex problem. Adults produce about $250 \mathrm{mg}$ of bilirubin per day (52) (3.6 $\mathrm{mg} / \mathrm{kg}$ per day), and the adult's liver may be capable of excreting 10 times the normal rate of bilirubin (53). Billing, Cole, and Lathe (54) calculated that small newborn infants have only $1-2 \%$ of the normal adult capacity for bilirubin excretion. Pearson (34) has calculated bilirubin production from red cell survival studies in newborns and points out that, based on serum bilirubin values normally found on the 3rd day of life, the liver in the newborn infant must have "considerable ability to conjugate and excrete bilirubin." Our findings support this conclusion and suggest that normal full-term infants have at least $15 \%$ of the adult capacity for bilirubin excretion.

We did not calculate bilirubin turnover in the erythroblastotic infants because of rapidly changing bilirubin values and uncertainty regarding albumin binding capacity in these infants. In the normal infants (maximum serum bilirubin, $8 \mathrm{mg} / 100 \mathrm{ml}$ ), the primary binding sites for bilirubin on albumin would not be saturated (55). Our calculations of bilirubin turnover do not consider the possibility of an enterohepatic circulation of bilirubin in the newborn (56). If such a circulation contributes significantly to the bilirubin load, the ability of the newborn to excrete bilirubin must be even greater than our calculations imply.

\section{ACKNOWLEDGMENTS}

It is a pleasure to acknowledge the technical assistance of Miss Ruth Cherry, Miss Marilyn Boyer, and Miss Josephine Neveska. We are grateful to Doctors W. D. Cochran, M. Sears, and D. Muirhead of the Boston Hospital for Women for permission to study their patients, and to Dr. S. Vivona, Walter Reed Army Institute of Research, for his statistical advice. We also wish to thank SSG Roland Lewis and the Medical Audio-Visual Department, Walter Reed Army Institute of Research, for their help.

This work was supported by U. S. Public Health Service grants HD 00050, HD 02777, and Tl-Am05581 and by a grant from the John A. Hartford Foundation, Inc. Dr. Nelson is the recipient of a Research Career Development Award from the National Institute of Child Health and Human Development. Dr. Nathan is the recipient of U. S. Public Health Service Research Career Development Award K03 AM35361.

\section{REFERENCES}

1. Coburn, R. F., W. S. Blakemore, and R. E. Forster. 1963. Endogenous carbon monoxide production in man. J. Clin. Invest. 42 : 1172.

2. Coburn, R. F., W. J. Williams, and R. E. Forster. 1964. Effect of erythrocyte destruction on carbon monoxide production in man. J. Clin. Invest. 43: 1098.

3. Coburn, R. F., W. J. Williams, P. White, and S. B. Kahn. 1967. The production of carbon monoxide from hemoglobin in vivo. J. Clin. Invest. 46: 346.

4. Sjöstrand, T. 1949. Endogenous formation of carbon monoxide in man under normal and pathological conditions. Scand. J. Lab. Invest. $1: 201$.

5. Sjöstrand, T. 1951. Endogenous formation of carbon monoxide. The $\mathrm{CO}$ concentration in the inspired and expired air of hospital patients. Acta Physiol. Scand. 22 : 137.

6. Sjorstrand, T. 1951. The in vitro formation of carbon monoxide in blood. Acta Physiol. Scand. $24: 314$.

7. Oski, F. A., A. A. Altman. 1962. Carboxyhemoglobin levels in hemolytic disease of the newborn. J. Pediat. $61: 709$.

8. Bjure, J., and S. P. Fällström. 1963. Endogenous formation of carbon monoxide in newborn infants. 1 . Nonicteric and icteric infants without blood group incompatibility. Acta Paediat. Scand. 52: 361.

9. Făllstrom, S. P., and J. Bjure. 1967. Endogenous formation of carbon monoxide in newborn infants. II. Rh hemolytic disease of the newborn. Acta Paediat. Scand. 56: 365.

10. Fällstrơm, S. P., and J. Bjure. 1968. Endogenous formation of carbon monoxide in newborn infants. III. ABO incompatibility. Acta Paediat. Scand. 57: 137.

11. Coburn, R. F., R. E. Forster, and P. B. Kane. 1965. Considerations of the physiological variables that determine the 
blood carboxyhemoglobin concentration in man. J. Clin. Invest. 44 : 1899.

12. Fallström, S. P. 1968. Endogenous formation of carbon monoxide in newborn infants. $\mathrm{V}$. On the relation between the carboxyhemoglobin concentration and the haemoglobin catabolism calculated from simultaneous determinations of carbon monoxide elimination and total haemoglobin. Acta Paediat. Scand. 57 : 487.

13. Wranne, L. 1967. Studies on erythrokinetics in infancy. VII. Quantitative estimation of hemoglobin catabolism by carbon monoxide technique in young infants. Acta Paediat. Scand. 56: 381 .

14. Wranne, L. 1967. Studies on erythrokinetics in infancy. VI. A method for the quantitative estimation of pulmonary excretion of carbon monoxide in infancy. Acta Paediat. Scand. 56: 374 .

15. Wranne, L. 1969. Studies on erythrokinetics in infancy. XIV . The relation between anemia and hemoglobin catabolism in Rh-hemolytic disease of the newborn. Acta Paediat. Scand. 58: 49.

16. Fällström, S. P., 1968. Endogenous formation of carbon monoxide in newborn infants. IV. On the relation between the blood carboxyhemoglobin concentration and the pulmonary elimination of carbon monoxide. Acta Paediat. Scand. 57: 321.

17. Coburn, R. F., W. J. Williams, and S. B. Kahn. 1966. Endogenous carbon monoxide production in patients with hemolytic anemia. J. Clin. Invest. 45: 460.

18. Coburn, R. F. 1967. Endogenous carbon monoxide production and body CO stores. Acta Med. Scand. Suppl. 472: 269.

19. Cross, K. W. 1949. The respiratory rate and ventilation in the newborn baby. J. Physiol. 109: 459.

20. Sjöstrand, T. 1949. A method for the determination of the total haemoglobin content of the body. Acta Physiol. Scand. 16: 211.

21. Natelson, S., and R. L. Stellate. 1963. Apparatus for extraction of gases for injection into the gas chromatograph. Anal. Chem. 35: 847.

22. Farhi, L. E., A. W. T. Edwards, and T. Hommà. 1963. Determination of dissolved $\mathrm{N}_{2}$ in blood by gas chromatography and (a-A) $\mathrm{N}_{2}$ difference. J. Appl. Physiol. 18: 97.

23. Chu, J., J. A. Clements, E. K. Colton, M. H. Kaus, A. Y. Sweet, and W. H. Tooley. 1967. Neonatal pulmonary ischemia. Part I. Clinical and physiological studies. Pediatrics. 40 (Suppl.): 709.

24. Drabkin, D. L., and J. H. Austin. 1935. Spectrophotometric studies. V. A technique for the analysis of undiluted blood and concentrated hemoglobin solutions. J. Biol. Chem. 112 : 105.

25. White, D., G. A. Haidar, and J. G. Rheinhold. 1958. Spectrophotometric measurement of bilirubin concentrations in the serum of the newborn by the use of a microcapillary method. Clin. Chem. 4: 211.

26. Vest, M., L. Strebel, and D. Hauenstein. 1965. The extent of "shunt" bilirubin and erythrocyte survival in the newborn infant measured by the administration of ("N) glycine. Biochem. J. 95: 11c.

27. Engel, R., P. D. Berk, F. L. Rodkey, R. B. Howe, and N. I. Berlin. 1969. Estimation of heme turnover and erythrocyte survival in man from clearance of bilirubin and from carbon monoxide production. Clin. Res. 17: 325 .

28. Ostow, J. D., and R. Schmid. 1963. The protein-binding of $\mathrm{C}^{14}$-bilirubin in human and murine serum. J. Clin. Invest. 42: 1286 .
29. Mollison, P. L., N. Veall, and M. Cutbush. 1950. Red cell and plasma volume in newborn infants. Arch. Dis. Childhood. 25: 242.

30. Nomof, N., J. Hopper, E. Brown, K. Scott, and R. Wennesland. 1954. Simultaneous determinations of the total volume of red blocd cells by use of carbon monoxide and chromium ${ }^{51}$ in healthy and diseased human subjects. J. Clin. Invest. 33 : 1382.

31. Usher, R., M. Shephard, and J. Lind. 1963. The blood volume of the newborn infant and placental transfusion. Acta Paediat. Scand. 52 : 497.

32. Sproul, A., and L. Smith. 1964. Bilirubin equilibration during exchange transfusion in hemolytic disease of the newborn. J. Pediat. 65: 12.

33. Vest, M. F. 1967. Studies on hemoglobin breakdown and incorporation of $\left({ }^{15} \mathrm{~N}\right)$ glycine into haem and bile pigment in the newborn. In Bilirubin Metabolism. A. D. Bouchier and B. H. Billing, editors. Blackwell Scientific Publications Ltd., Oxford. 47 .

34. Pearson, H. A. 1967. Life-span of the fetal red blood cell. J. Pediat. 70: 166.

35. Garby, L., S. Sjölin, and J. C. Vuille. 1964. Studies on erythrokinetics in infancy. V. Estimations of the lifespan of red cells in the newborn. Acta Paediat. Scand. 53: 165.

36. Mollison, P. L. 1948. Physiological jaundice of the newborn. Some new measurements of the factors concerned. Lancet. $1: 513$.

37. Oh, W., and J. Lind. 1966. Venous and capillary hematocrit in newborn infants and placental transfusion. Acta Paediat. Scand. 55: 38 .

38. McCue, C. M., F. B. Garner, W. G. Hurt, E. C. Schelin, and A. R. Sharpe, Jr. 1968. Placental transfusion. J. Pediat. 72: 15 .

39. Oski, F. A., and J. L. Naiman. 1966. Hematologic problems in the newborn. W. B. Saunders Company, Philadelphia. 10.

40. Glass, H. I., A. Brant, J. C. Clark, A. C. deGaretta, and L. G. Day. 1968. Measurement of blood volume using red cells labeled with radioactive carbon monoxide. $\mathrm{J}$. $\mathrm{Nucl}$. Med. 9: 571 .

41. Robinson, S. H. 1968. The origins of bilirubin. $N$. Engl. J. Med. $279: 143$.

42. Levitt, M., B. A. Schacter, A. Zipursky, and L. G. Israels. 1968. The nonerythropoietic component of early bilirubin. J. Clin. Invest. 47: 1281

43. London, I. M., R. West, D. Shemin, and D. Rittenberg. 1950. On the origin of bile pigment in normal man. J. Biol. Chem. 184: 351.

44. Gray, C. H., A. Neuberger, and P. H. A. Sneath. 1950. Studies in congential porphyria. II. Incorporation of ${ }^{15} \mathrm{~N}$ in in the stercobilin in the normal and in the porphyric. Biochem. J. $47: 87$.

45. White, P., R. F. Coburn, W. J. Williams., M. I. Goldwein, M. L. Rother, and B. C. Shafer. 1967. Carbon monoxide production associated with ineffective erythropoiesis. $J$. Clin. Invest. 12: 1986.

46. Lathe, G. H., and M. Walker. 1958. An enzymatic defect in human neonatal jaundice and in Gunn's strain of jaundiced rats. Biochem. J. 70: 705.

47. Brown, A. K., W. W. Zueler, and H. Burnett. 1958. Studies on the neonatal development of the glucuronide conjugating system. J. Clin. Invest. 37: 332. 
48. Vest, M. 1958. Insufficient glucuronide formation in the newborn infant and its relationship to the pathogenesis of icterus neonatorum. Arch. Dis. Childhood. 33: 473.

49. Strebel, L., and G. B. Odell. 1969. UPD glucuronyl transferase in rat liver. Genetic variation and maturation. Pediat. Res. 3: 351.

50. DiToro, R., L. Lupi, and V. Ansanelli. 1968. Glucuronation of the liver in premature babies. Nature (London). 219: 265.

51. Gartner, L. M., and I. M. Arias. 1969. Transfer of bilirubin from blood to bile in neonatal guinea pigs. Pediat. Res. 3: 171.
52. Crosby, W. H. 1955. The metabolism of hemoglobin and bile pigment in hemolytic disease. Amer. J. Med. 18: 112.

53. Lester, R. L., and R. Schmid. 1964. Bilirubin metabolism. N. Engl. J. Med. 270: 779.

54. Billing, B. H., P. G. Cole, and G. H. Lathe. 1954. Increased plasma bilirubin in newborn infants in relation to birth weight. Brit. Med. J. 2 : 1263.

55. Odell, G. B. 1959. The dissociation of bilirubin from albumin and its clinical implications. J. Pediat. 55: 268.

56 Odell, G. B. 1967. "Physiologic" hyperbilirubinemia in the neonatal period. N. Engl. J. Med. 277 : 193. 